Anne Kristine Bergem (f. 1969) er leder av Norsk psykiatrisk forening og fagrådgiver i Rådet for psykisk helse. Hun er tidligere overlege/avdelingsoverlege ved Regional sikkerhetsavdeling Helse Sør-Øst.

Forfatter har fylt ut ICMJE-skjemaet og oppgir ingen interessekonflikter.

\section{Litteratur}

1. Hovland M. Rettstryggleik for den psykisk sjuke. Tidsskr Nor Legeforen 2016: 136: 1099-101.

2. Lov om pasient- og brukerrettigheter (pasientog brukerrettighetsloven). Kapittel 4 A. Helsehjelp til pasienter uten samtykkekompetanse som motsetter seg helsehjelpen mv. https://lovdata.no/ dokument/NL/lov/1999-07-02-63/KAPITTEL 5\# KAPITTEL 5 (28.5.2016)

3. Lov om helsepersonell m.v. (helsepersonelloven) kapittel 2 \& 7. https://lovdata.no/dokument/NL/lov/ 1999-07-02-64/KAPITTEL_2\#KAPITTEL_2 (28.5.2016).

4. Lov om straff (straffeloven) kapittel $3 \S 17$ https://lovdata.no/dokument/NL/lov/2005-05-2028/KAPITTEL_1-3\#KAPITTEL_1-3 (28.5.2016).

5. Trompenaars F. Hampden-Turner C. Riding the waves of culture. Understanding cultural diversity in business. London: Intercultural Management Publishers NV, 1997

6. Prop. 122 L (2014-2015). Endringer i straffeloven 2005 mv. (strafferettslige særreaksjoner m.m.). www.regjeringen.no/no/dokumenter/prop.-122-l20142015/id2412699/?ch=3 (28.5.2016).

7. Nyttingnes O, Elvemo O, Gaarder P et al. Frivillighet før tvang: tiltak for å redusere omfang av tvangsinnleggelser til psykisk helsevern. Oslo: Rådet for psykisk helse, 2010

8. Fuglseth NLD, Gjestad R, Mellesdal L et al. Factors associated with disallowance of compulsory mental healthcare referrals. Acta Psychiatr Scand 2016; 133: 410-8.

Mottatt 28.5. 2016 og godkjent 13.6. 2016. Redaktør: Ketil Slagstad.

> Se også side 1099

Publisert først på nett.

\title{
På tide å innføre spesialisteksamen
}

Når jeg tenker tilbake på min egen spesialistutdanning, slår det meg at man praktisk talt kunne bli spesialist uten å måtte dokumentere bestemte krav til kunnskap og ferdigheter. Så lenge man deltok i det daglige arbeidet $\mathrm{i}$ de godkjente institusjonene $\mathrm{i}$ et gitt antall år, var det automatikk i å bli godkjent spesialist. Nå vet enhver at det kan være store forskjeller i kunnskapsnivået blant våre leger. Faglig nivå er avhengig av mange faktorer, blant annet interesse for faget, evnen til å lære og kvaliteten på utdanningen. Men det er stort sett ingen kvalitetskontroll på slutten av spesialistutdanningen, og det er vel ekstremt sjelden at noen blir oppsagt eller nektet spesialistgodkjenning.

I flere europeiske land kreves bestått spesialisteksamen for å bli spesialist i hud- og veneriske sykdommer. Norge er et av de få landene som ikke krever spesialisteksamen. Min erfaring som professor i både Norge og Sveits har overbevist meg om at bestått spesialisteksamen bør innføres som spesialistkrav i Norge. I Sveits er det en meget omfattende og vanskelig spesialisteksamen. Assistentlegene under utdanning starter tidlig å forberede seg til eksamen. De vet at kravene er store. Derfor har de også et meget høyt kunnskapsnivå når de er ferdige med hele forløpet. Noen vil hevde at det etter medisinsk embetseksamen må være slutt på eksamener. Men vi skylder samfunnet og våre pasienter at vi har et godt dokumentert kunnskapsnivå for å få spesialistgodkjenning. Dette var grunnlaget for medisinsk embetseksamen og bør også gjelde for retten til å kalle seg spesialist.

\section{Lasse R. Braathen}

lasse.r.braathen@bluewin.ch

Lasse R. Braathen (f. 1942) er professor emeritus ved Medisinsk fakultet, Universitetet i Bern, Sveits.

Ingen oppgitte interessekonflikter.

Mottatt 26.5. 2016 og godkjent 31.5. 2016. Redaktør: Ketil Slagstad.

Publisert først på nett. 